\title{
Content Validity of the HIIT Training Program in Special Preparations to Improve the Dominant Biomotor Components of Kumite Athletes
}

\author{
Dewangga Yudhistira ${ }^{1, *}$, Wawan Sundawan Suherman ${ }^{1}$, Arodotonafo Wiratama ${ }^{2}$, \\ Uden Kusuma Wijaya ${ }^{2}$ Paryadi $^{3}$, Mohammad Faruk ${ }^{4}$, Husnul Hadi ${ }^{5}$, Samsuddin Siregar ${ }^{6}$, \\ Jufrianis $^{7}$, Kukuh Wahyudin Pratama ${ }^{8}$ \\ ${ }^{1}$ Faculty of Sport Sciences, Yogyakarta State University, Yogyakarta, Indonesia \\ ${ }^{2}$ Faculty of Sport Science, Jakarta State University, Indonesia \\ ${ }^{3}$ Faculty of Teacher Training and Education, Mulawarman University, Indonesia \\ ${ }^{4}$ Faculty of Sport Science, Surabaya State University, Surabaya, Indonesia \\ ${ }^{5}$ Faculty of Sport Science, Semarang PGRI University, Indonesia \\ ${ }^{6}$ Faculty of Sport Science, Medan State University, Medan, Indonesia \\ ${ }^{7}$ Department of Physical Education, Health and Recreation, Universitas Pahlawan Tuanku Tambusai, Indonesia \\ ${ }^{8}$ Institute of Advanced Science, Engineering and Education (IASSE), Selangor, Malaysia
}

Received May 8, 2021; Revised August 5, 2021; Accepted September 8, 2021

\section{Cite This Paper in the following Citation Styles}

(a): [1] Dewangga Yudhistira, Wawan Sundawan Suherman, Arodotonafo Wiratama, Uden Kusuma Wijaya, Paryadi, Mohammad Faruk, Husnul Hadi, Samsuddin Siregar, Jufrianis, Kukuh Wahyudin Pratama , "Content Validity of the HIIT Training Program in Special Preparations to Improve the Dominant Biomotor Components of Kumite Athletes," International Journal of Human Movement and Sports Sciences, Vol. 9, No. 5, pp. 1051 - 1057, 2021. DOI: 10.13189/saj.2021.090527.

(b): Dewangga Yudhistira, Wawan Sundawan Suherman, Arodotonafo Wiratama, Uden Kusuma Wijaya, Paryadi, Mohammad Faruk, Husnul Hadi, Samsuddin Siregar, Jufrianis, Kukuh Wahyudin Pratama (2021). Content Validity of the HIIT Training Program in Special Preparations to Improve the Dominant Biomotor Components of Kumite Athletes. International Journal of Human Movement and Sports Sciences, 9(5), 1051 - 1057. DOI: 10.13189/saj.2021.090527.

Copyright $\odot 2021$ by authors, all rights reserved. Authors agree that this article remains permanently open access under the terms of the Creative Commons Attribution License 4.0 International License

\begin{abstract}
Background: Kumite is a physical contact fight in a karate match characterized by short explosive and intermittent movements. Kumite needs endurance, power, and agility. To achieve optimal performance, special training must be programmed. Purpose: This study aims to test the content validity of the HIIT training program that was created in a special preparation to improve the dominant motor components, namely endurance, power, and agility in the performance of Kumite athletes. Methods: This is development research with a quantitative approach. This research was carried out in 3 stages. The first stage was to analyze journals, eBooks, and textbooks to design a HIIT program. This was followed by the second stage in the form of the Delphi technique by meeting directly with experts to conduct an assessment of the HIIT program created. The third stage is data analysis using the content
\end{abstract}

validity ratio (CVR) formula to test content validity. Participants consisted of 10 experts and documents. Results: The results of the content validity test using the content validity ratio (CVR) formula found that all assessment items from 10 experts showed CVR values of 0.8 and 1.00. In other words, the assessment results can be categorized as having high content validity. Conclusion: The HIIT training program in special preparation to improve the dominant biomotor components of endurance, power, and agility developed by the author has high content validity so it is suitable for use in karate athletes, especially Kumite.

Keywords Content Validity, HIIT Program, Kumite Athletes 


\section{Introduction}

Kumite is included in one of the matches in karate. Kumite is often referred to as a fight involving two athletes who aim to achieve victory by hitting and kicking techniques to get points. The characteristics of kumite movements are explosive and intermittent with a duration of 1-3 seconds, while intensive attacks last about 18 seconds [1][2][3][4][5][6][11]. Physical factors become very important because kumite requires good endurance, power, and agility biomotor components [7][8]. When performing attack and defense techniques, it takes power and agility to avoid the opponent's attack [7].

The energy system in kumite is aerobic and anaerobic where the anaerobic energy system in this case is more dominant when attacking and defending [8]. Anaerobic is known as a movement in a short time that uses the phosphagen system. The literature states that a good anaerobic energy system is a determinant in dominant sports using power and agility [7][9][10]. Therefore, it is necessary to develop an exercise program that is appropriate for periodization.

Periodization is a concept to divide training into smaller segments so that it becomes structured, systematically varied, methodical in the short, medium, and long term to achieve achievement [12][13][14][15][16]. The literature describes a comparison of strength and agility endurance training carried out using the concept of periodization where it is more desirable and effective than non-periodization [17]. The concept of periodization is therefore an important part of developing a physical exercise program and preventing injury [19][20][21][22][23]. The training period is divided into preparation, competition, and transition. The preparatory phase is divided into general and specific. The special preparations aim to improve the physical aspects combined with techniques according to the characteristics of the match [14].

Based on field observations, it was found that the problem with compiling a physical exercise program in kumite was the training method that was not following the characteristics of the special preparation phase. This is because special preparation prioritizes physical exercises that are varied with techniques that aim to make athletes in pre-competition focus on developing match strategies and mental mastery. Events in the field show that in giving doses of exercise volume tends to be high so that it has an impact on injury and overtraining. The characteristics of special preparatory physical exercise should be more with a relatively decreased volume where the intensity is also increased but still adjusted [36][40]. The literature states that physical exercise combined with match simulation techniques is a good and useful approach to develop the highest energy phosphates, namely alactite and lactite, and can reduce fat [36][40].

The training method that is following the characteristics of kumite is the high-intensity interval training (HIIT) method. However, research related to HIIT training methods specifically for kumite athletes is still minimal, coupled with the lack of optimal HIIT training to increase power, endurance, and agility. The literature states that a special training program to develop kumite characteristics should be programmed [6]. The purpose of this study was to test the content validity of the development of a HIIT training program in the periodization of special preparations to increase the dominant biomotor components, including power, endurance, and agility in the performance of kumite athletes. This study will present the methods, results, discussion, and conclusions that focus on the content validity of the HIIT training program.

\section{Materials and Methods}

This research is development research with a quantitative approach. [41][42][43]. The participants are 10 experts who are competent in each field. 7 experts are nationally certified physical trainers, then 3 experts are national certified kumite special karate trainers holding black belts DAN 2. There are several stages in this research. The first stage is the investigation done by researchers through documents in the form of an ebook, textbook, and journal article which is relevant to develop a HIIT training program, then the second stage is using Delphi technique [44] where a researcher found those 10 experts to rate HIIT training program which is structured. Then the third stage is to analyze the examination of 10 experts by implementing a content validity ratio (CVR) formula [42][46]. The following is Lawshe's (CVR) formula [45].

$$
\begin{gathered}
\text { CVR }=\left(\mathrm{n}_{\mathrm{e}}-\mathrm{N} / 2\right) /(\mathrm{N} / 2) \\
\mathrm{n}_{\mathrm{e}}: \text { The number of panelists who answered } \\
\mathrm{N}: \text { The total number of panelist }
\end{gathered}
$$

\section{Results}

The results of the analysis of documents, journals, eBooks and textbooks have produced a high intensity interval training (HIIT) program in a special preparation phase to improve the physical components consisting of power, endurance and agility in the performance aspects of karate athletes in the kumite category. Then, the draft high intensity interval training (HIIT) training program has been assessed by $10 \mathrm{CVR}$ experts. The results are presented in table 1 . 
Table 1. Experts' Assessment Results in the HIIT Program

\begin{tabular}{|c|c|c|c|c|c|c|c|c|c|c|c|c|}
\hline \multirow{2}{*}{ No } & \multirow{2}{*}{ Indicators } & \multicolumn{10}{|c|}{ Number of Panel } & \multirow{2}{*}{$\begin{array}{c}\text { CVR } \\
\text { Value }\end{array}$} \\
\hline & & 1 & 2 & 3 & 4 & 5 & 6 & 7 & 8 & 9 & 10 & \\
\hline 1 & The intensity of the HIIT program fits the senior kumite athletes & 1 & 1 & 1 & 1 & 1 & 1 & 1 & 1 & 1 & 1 & 1 \\
\hline 2 & $\begin{array}{l}\text { The interval given is fits with the ability level of senior kumite } \\
\text { athletes }\end{array}$ & 1 & 1 & 1 & 1 & 1 & 1 & 1 & 1 & 1 & 1 & 1 \\
\hline 3 & $\begin{array}{l}\text { The set is given according to the ability level of the senior kumite } \\
\text { athlete }\end{array}$ & 1 & 1 & 1 & 1 & 1 & 1 & 1 & 1 & 1 & 1 & 1 \\
\hline 4 & The frequency given is in accordance with HIIT training norms & 1 & 1 & 1 & 1 & 1 & 1 & 1 & 1 & 1 & 1 & 1 \\
\hline 5 & $\begin{array}{l}\text { The movements in each post are in accordance with the agility } \\
\text { training objectives of the kumite }\end{array}$ & 0 & 1 & 1 & 1 & 1 & 1 & 1 & 1 & 1 & 1 & 0.8 \\
\hline 6 & $\begin{array}{l}\text { The movement in each post corresponds to the goal of power } \\
\text { training in the kumite }\end{array}$ & 1 & 1 & 1 & 1 & 1 & 1 & 1 & 1 & 1 & 1 & 1 \\
\hline 7 & $\begin{array}{l}\text { The movements in each post correspond to the objectives of the } \\
\text { endurance training on the kumite }\end{array}$ & 1 & 1 & 0 & 1 & 1 & 1 & 1 & 1 & 1 & 1 & 0.8 \\
\hline 8 & $\begin{array}{l}\text { The number of movements is in accordance with the goals of HIIT } \\
\text { training }\end{array}$ & 1 & 1 & 1 & 1 & 1 & 1 & 1 & 1 & 1 & 1 & 1 \\
\hline 9 & $\begin{array}{l}\text { The characteristics of the training model is in accordance with the } \\
\text { specific periodization stage }\end{array}$ & 1 & 1 & 1 & 1 & 1 & 1 & 1 & 1 & 1 & 1 & 1 \\
\hline 10 & The training suits the anaerobic system of the kumite & 1 & 1 & 1 & 1 & 1 & 1 & 1 & 1 & 1 & 1 & 1 \\
\hline 11 & $\begin{array}{l}\text { The equipment used is in accordance with the objectives of HIIT } \\
\text { training }\end{array}$ & 1 & 1 & 1 & 1 & 1 & 1 & 1 & 1 & 1 & 1 & 1 \\
\hline 12 & Training period of 6 weeks & 1 & 1 & 1 & 1 & 1 & 1 & 1 & 1 & 0 & 1 & 0.8 \\
\hline
\end{tabular}

The results of the assessment of 10 experts were then calculated using the content validity ratio (CVR) formula and resulted in the CVR value of 0.8 to 1 . Thus, validity can be categorized as good or high. In other words, 10 panelists have a strong similarity in assessing the value of the HIIT program in the special preparation periodization to increase the dominant biomotor components, namely endurance, power and agility in kumite athletes. In other words, 10 panelists have a strong similarity in assessing the value of the HIIT program in the special preparation periodization to increase the dominant biomotor components, namely endurance, power and agility in kumite athletes.

Table 2. HIIT Program Special Periodization for Kumite Athletes

\begin{tabular}{|c|c|c|c|}
\hline Week & Meeting & Training Item & Training Dose \\
\hline $1-2$ & $1-6$ & $\begin{array}{l}\text { Pos 1: Explosive pushup } \\
\text { Pos 2: Squat jump } \\
\text { Pos 3: V situp } \\
\text { Pos 4: Punch technique } \\
\text { Pos 5: Superman twist } \\
\text { Pos 6: Diamond pushup } \\
\text { Pos 7: High Knee } \\
\text { Pos 8: Crunch } \\
\text { Pos 9: Kick technique } \\
\text { Pos 10: Burpee }\end{array}$ & $\begin{array}{c}\text { Frequency: } 3 \\
\text { Intensity: High } \\
\text { Set: } 4 \\
\text { Work time: } 25 \text { seconds } \\
\text { Interval: } 20 \text { seconds } \\
\text { Recovery: } 3 \text { minutes }\end{array}$ \\
\hline $3-4$ & $7-12$ & $\begin{array}{l}\text { Pos 1: Pushup Clapping } \\
\text { Pos 2: Lateral hurdle jump } \\
\text { Pos 3: Supine Medicine Ball Core Pass } \\
\text { Pos 4: Kick technique } \\
\text { Pos 5: Backup } \\
\text { Pos 6: Triceps Dip on Chair } \\
\text { Pos 7: Split jump } \\
\text { Pos 8: Leg raises } \\
\text { Pos 9: Punch technique }\end{array}$ & $\begin{array}{c}\text { Frequency: } 3 \\
\text { Intensity: High } \\
\text { Set: } 3 \\
\text { Work time: } 25 \text { seconds } \\
\text { Interval: } 20 \text { seconds } \\
\text { Recovery: } 4 \text { minutes }\end{array}$ \\
\hline $5-6$ & $13-18$ & $\begin{array}{l}\text { Pos 1: Medicine Ball Chest Pass in Wall } \\
\text { Pos 2: Hurdle Jump } \\
\text { Pos 3: Punch and kick techniques } \\
\text { Pos 4: Medicine Ball situps chest pass } \\
\text { Pos 5: Squat and Jumping jack } \\
\text { Pos 6: Punch and kick techniques } \\
\text { Pos 7: Resistance Band Row } \\
\text { Pos 8: Resistance Band Squat Jump } \\
\text { Pos 9: Punch and kick techniques }\end{array}$ & $\begin{array}{c}\text { Frequency: } 3 \\
\text { Intensity: High } \\
\text { Set: } 2 \\
\text { Work time: } 25 \text { seconds } \\
\text { Interval: } 20 \text { seconds } \\
\text { Recovery: } 5 \text { minutes }\end{array}$ \\
\hline
\end{tabular}




\section{Discussion}

Kumite is a match in karate that has fast characteristics and maximum power. Literature states that the characteristic of kumite is intermittent [47]. The anaerobic energy system has an important role to do fast moves, but the aerobic energy system also plays role in conducting recovery between match one and the next [47][48]. Literature states that trainers are suggested to train both energy systems according to Kumite athlete competition demand [47].

Periodization of training is a flexible concept. Periodization cannot run when it is being run rigidly [14]. Trainers are required to master knowledge about branches of sport to enable in managing the training program [15]. The training periodization concept becomes an integral part to compile the corresponding training program, literature states that implementing the training periodization well is effective to improve power [19]. The preparation phase has the purpose to form, develop physiological systems such as cardiovascular and neuromuscular [49], besides that, to form, develop physical components such as power, speed, endurance, and agility [49]. This is following guidelines for lower volume dose settings, higher intensity, and more extended recovery which serves to reduce and assist the potential for fatigue and maximize techniques that develop on more complex concepts [28].

Long-term athlete development (LTAD) theory states that athlete ages ranged from 19-23. The purpose of training is to maximize and integrate mental, cognitive, and physical development [24][63]. In another literature, it is stated that ages 19 and over aim to develop further in terms of technique, strategy as well as improve and maintain the physical component [24]. Scientific evidence states that the implementation of this long-term athlete development is an important instrument to achieve lifelong physical literacy in physical activities involvement [25][26]. Therefore, Kumite athletes aged 19-23 for special physical training must be structured to increase endurance, power, and agility.

The biomotor component which is dominant in kumite is endurance, power, and agility. Endurance is an athlete's ability to against fatigue when conducting training and match at relatively the same time [50]. Aerobic endurance is needed by kumite athletes when carrying out large numbers of attacks and continuing the match from round to round. This is confirmed by the literature that aerobic endurance is an important component of fitness to improve performance and health [51]. Power is an important component for kumite athletes, power is defined as a style that distributes energy to finish the maximum task and is often known as a combination of power and speed [52]. Literature states that power training result improvement from functional capacity and muscle power also become the greatest power for an athlete [53]. Power is closely related to agility because agility is a product of several physical components which are flexibility, speed, and power [54]. Kumite needs agility because every movement in a match has an element of agility such as attacking, defending, and dodging [43]. Therefore, training programs must be structured by observing aerobic and anaerobic energy systems to improve the endurance of power and agility. Reviewed from movement pattern that martial arts are fast, interspersed with intervals, movement pattern which is corresponding to that is high intensity of interval training which is interspersed with technique variations [29][30][31][32][33][34][35].

High-intensity interval training (HIIT) is a training program which contains repetitive motion with high intensity which aim to improve important physical aspect for athlete, HIIT training can be combined with technical motion, body weight, and attribute weight [36][37][38][6][2]. HIIT is a special method for sport with a match duration of around 1-8 minutes, The energy which is used is glycolysis and oxidative systems interaction [36][37][38][6]. In karate, the HIIT method has a positive impact on cardiorespiratory, aerobic, and anaerobic metabolism and functional performance [39]. HIIT is marked with fast movement interspersed with short intervals then back to fast motion, or fast movements followed by repeated slow movements [37]. HIIT is performed relatively short, ranging from 10 minutes in one training session to no more than 30 minutes including warm-up, intervals, recovery, and relaxation [37].

Several kinds of research stated that HIIT is speed and power training with maximum motion or repetitive motion which involves short intervals of maximal intensity with a working time of 45 seconds to 2 minutes [55][56][36], but so far the existing training to increase endurance, power, and agility in kumite have not been carefully observed that training must be adapted to the energy system, movement characteristics and training periodization. Bompa \& Buzzichelli stated that training at a special periodization of relatively high intensity but adapted to recovery so that athletes do not experience injury and overtraining, while the training volume is progressively reduced such as reducing the number of training items, the number of sets, and repetitions [13]. Several kinds of literature explained that the degradation of training charge progressively is proven able to avoid excessive training, eliminate boredom, optimize recovery and improve performance [57][58]. The characteristic of progressive weight degradation is to maintain intensity but decrease volume progressively until the end of the training [57][58]. Based on the elaboration, the author compiles a physical training program that combines techniques using HIIT method that can be applied in special preparation periodization, with the hope that the trainer can use it to improve the dominant physical components in kumite, which are endurance, power, and agility. However, to structure a 
program, validity must be conducted so that the program can be said as valid.

Validity is a very important part of the design development process [42]. Validity describes the extent to which the design of HIIT training programs in specific preparations improves the physical aspects of power, endurance, agility in kumite athletes. There are several types of validity: criterion validity, construct validity, and content validity. In the early stage to design this validity program, It is often used to refer to the extent to which an item is related to the studied content or conceptual dimension [59] [42][41][60].

The result of the validity test using the CVR formula is that the assessment items from 10 experts of special kumite HIIT training program show CVR values of 0.8 and 1.00 then from the result of research, the content validity can be categorized as high, following literature explanation that scores from +1 to -1 positive score at least half of the experts rated the item as essential. If the CVR value is greater than 0 , then the more essential it is, or the level of content validity is high [61]. That argument is strengthened with other literature that CVR ratio with single indicator -1 to1, the CVR score is closer to 1 then the content validity will get higher [42][45].

\section{Conclusions}

Based on the results and discussion of this study, it can be concluded that the HIIT training program in the kumite category of karate in special preparation shows a high content validity value. Thus, the program developed is feasible and can be used to increase the dominant bimotor components in kumite, namely endurance, power and agility. However, the program still needs further development and its effectiveness needs to be tested through experimental methods.

\section{Acknowledgement}

The author would like to thank the physical coach, karate coach, and the Yogyakarta State University who have provided support so that this article can be completed in a proper manner.

\section{REFERENCES}

[1] Petri, K., Lichtenstein, M., Bandow, N., Campe, S., Wechselberger, M., Sprenger, D. "Analysis of anticipation by $3 \mathrm{D}$ motion capturing-a new method presented in karate kumite," Journal of Sports Sciences, vol. 35, no. 2, pp. 130-135., 2017.

[2] Gauchard, G. C., Lion, A., Bento, L., Perrin, P. P., \& Ceyte,
H. "Postural control in high-level kata and kumite karatekas," Movement Sport Sciences, vol. 2, pp. 21-26, 2018.

[3] Filingeri, D., Bianco, A., Zangla, D., Paoli, A., \& Palma, A, "Is karate effective in improving postural control?," Archives of Budo, vol 8, no. 4, pp. 203-206, 2012.

[4] Nichas, A., Shaw, B. S., Millard, L., Breukelman, G. J., \& Shaw, I, "Kinanthropometric attributes of elite South African male kata and kumite karateka". Age (years)," vol. 31, no. 14.02 , pp. 28-25., 2020.

[5] Lisowska, A. M., Murawa, M., \& Ogurkowska, M, "isokinetic assessment of knee joint muscles in shotokan karate kata athletes," ARCHIVES OF BUDO, vol. 16, pp. 61-66, 2020.

[6] Ojeda-Aravena, A., Herrera-Valenzuela, T., García García, J. M., \& Ramirez-Campillo, R., "Six weeks of HIIT based on repeated 5-meter sprints vs. countermovement jumps: effects on physical performance among karate athletes. A pilot-study". Ido Movement for Culture Journal of Martial Arts Anthropology, vol. 20, no.2, pp. 24-32.,2019 2019.

[7] Alp, M., \& Gorur, B, "Comparison of Explosive Strength and Anaerobic Power Performance of Taekwondo and Karate Athletes.," Journal of Education and Learning, vol. 9, no. 1, pp. 149-155, 2020.

[8] SAVAŞ, S., \& UĞRAŞ, A, "Sekiz haftalık sezon öncesi antrenman programının üniversiteli erkek boks, taekwondo ve karate sporcularının fiziksel ve fizyolojik özellikleri üzerine olan etkileri”. Gazi Üniversitesi Gazi Eğitim Fakültesi Dergisi, vol. 24, no. 3, pp. 257-274, 2004.

[9] Roschel, H., Batista, M., Monteiro, R., Bertuzzi, R. C., Barroso, R., Loturco, I., ... \& Franchini, E., "Association between neuromuscular tests and kumite performance on the Brazilian Karate National Team," Journal of sports science \& medicine. vol . 8, no. (CSSI3), pp.20, 2009.

[10] Ozan M, "Sporcularda kol ve bacak wingate testleri ile anaerobik gücün değerlendirilmesi," Selçuk Üniversitesi Beden Eğitimi ve Spor Anabilim Dalı (Doctoral dissertation), 2013.

[11] Üstündağ, B., Kocahan, T., Tortu, E., Karaman, G., \& Deliceoğlu, G. "Farklı Branşlardaki Erkek Milli Takım Sporcularının Anaerobik Güç ve Kapasitelerinin İncelenmesi," Gaziantep Üniversitesi Spor Bilimleri Dergisi, vol. 2, no. 2, pp. 57-65, 2017.

[12] Ravier, G., Dugue, B., Grappe, F., \& Rouillon, J. D. "Maximal accumulated oxygen deficit and blood responses of ammonia, lactate and $\mathrm{pH}$ after anaerobic test: a comparison between international and national elite karate athletes," International journal of sports medicine, vol 27, no. 10 , pp. 810-817, 2006.

[13] Bompa, T. O., \& Buzzichelli, C, Theory and Methodology of Training, USA: Human Kinethic, 2018.

[14] Hausswirth, C., \& Mujika, I. , Recovery for performance in sport, USA: Human Kinetics, 2013.

[15] Lyakh, V., Mikołajec, K., Bujas, P., \& Litkowycz, R, "Review of Platonov's "Sports Training Periodization. General Theory and its Practical Application"-Kiev: Olympic Literature, 2013 (part two," Journal of Human Kinetics, vol. 46, no. 1, pp. 273-278, 2014. 
[16] Fisher, J. P., \& Csapo, R. "Periodization and Programming in Sports"., Multidisciplinary digital publishing institute is a publisher of open access scientific journal, 2021.

[17] Afonso, J., Rocha, T., Nikolaidis, P. T., Clemente, F. M., Rosemann, T., \& Knechtle, B, "A systematic review of meta-analyses comparing periodized and non-periodized exercise programs: Why we should go back to original research," Frontiers in physio vol. 10, pp.1023, 2019.

[18] Bartolomei, S., Hoffman, J. R., Merni, F., \& Stout, J. R., "A comparison of traditional and block periodized strength training programs in trained athlete," The Journal of Strength \& Conditioning Research, vol. 28, no. 4, pp. 990-997, 2014.

[19] J. Kiely, "Periodization theory: confronting an inconvenient truth," Sports Medicine, vol. 48, no. 4, pp. 753-764., 2018.

[20] Painter, K. B., Haff, G. G., Ramsey, M. W., McBride, J., Triplett, T., Sands, W. A., ... \& Stone, M. H, "Strength gains: Block versus daily undulating periodization weight training among track and field athletes.," International journal of sports physiology and performance, vol, 7, no. 2, pp. 161-169, 2012.

[21] Kiviniemi, A. M., Tulppo, M. P., Hautala, A. J., Vanninen, E., \& Uusitalo, A. L. T. "Altered relationship between R $\mathrm{R}$ interval and $\mathrm{R}-\mathrm{R}$ interval variability in endurance athletes with overtraining syndrome," Scandinavian journal of medicine \& science, vol. 24, no.2, pp. e77-e85, 2014

[22] Miranda, F., Simao, R., Rhea, M., Bunker, D., Prestes, J., Leite, R. D., ... \& Novaes, J,. "Effects of linear vs. daily undulatory periodized resistance training on maximal and submaximal strength gains". The Journal of strength \& conditioning research, vol. 25, no.7, pp.1824-1830, 2011

[23] Phillips, M. B., Lockert, J. A., Rosemond, L. D., \& Lockert, J. "Tools and Benefits of Periodization: Developing an Annual Training Plan and Promoting Performance Improvements in Athletes," Sport Journal., 2016.

[24] Williams, T. D., Tolusso, D. V., Fedewa, M. V., \& Esco, M. $\mathrm{R}$ "Comparison of periodized and non-periodized resistance training on maximal strength: a meta-analysis," Sports medicine, vol. 47, no. 10, pp. 2083-2100., 2017.

[25] Balyi, I., Way, R., \& Higgs, C, Long-term athlete development, USA : Human Kinetics, 2013.

[26] Lloyd, R. S., \& Oliver, J. L "The youth physical development model: A new approach to long-term athletic development," Strength \& Conditioning Journal, vol. 34, no. 3, pp. 61-72, 2012.

[27] Granacher, U., \& Borde, R. "Effects of sport-specific training during the early stages of long-term athlete development on physical fitness, body composition, cognitive, and academic performances," Frontiers in physiology, vol. 8, no. 8, p. 10, 2017.

[28] Haff, G. G., \& Triplett, N. T., "Essentials of strength training and conditioning 4th edition," USA: Human kinetics., 2015.

[29] Franchini, E., Cormack, S., \& Takito, M. Y. "Effects of high-intensity interval training on olympic combat sports athletes' performance and physiological adaptation: A systematic review.," The Journal of Strength \& Conditioning Research, vol. 33, no. 1, pp. 242-252, 2019.
[30] Chaabene, H., Negra, Y., Bouguezzi, R., Mkaouer, B., Franchini, E., Julio, U., \& Hachana, Y., "Physical and physiological attributes of wrestlers: an update," The Journal of Strength \& Conditioning Research, vol. 31, no. 5, pp. 1411-1442., 2017.

[31] Franchini, E., Brito, C. J., Fukuda, D. H., \& Artioli, G. G., "The physiology of judo-specific training modalities.," The Journal of Strength \& Conditioning Research,, vol. 28, no. 5, pp. 1474-1481, 2014.

[32] Franchini, E., \& Takito, M. Y., "Olympic preparation in Brazilian judo athletes: description and perceived relevance of training practices.," The Journal of Strength \& Conditioning Research, vol. 28, no. 6, pp. 1606-1612., 2014.

[33] Herrera-Valenzuela, T., Zapata-Bastías, J., Guajardo-Medrano, M., Pons-Vargas, G., Valdés-Badilla, P., Ferreira Da Silva Santos, J., ... \& Orihuela, P "Can simulation tasks reproduce the taekwondo match physiological responses?.," Archives of budo science of martial arts. Vol. 14, pp. 25-31, 2018.

[34] Nakamura, F. Y., Pereira, L. A., Abad, C. C. C., Franchini, E., \& Loturco, I. "Cardiac autonomic and neuromuscular responses during a karate training camp before the 2015 Pan American games: a case study with the Brazilian national team.," International journal of sports physiology and performance". Vol. 11, no.6, pp.833-837, 2016.

[35] Turner, A., James, N., Dimitriou, L., Greenhalgh, A., Moody, J., Fulcher, D., ... \& Kilduff, L "Determinants of olympic fencing performance and implications for strength and conditioning training," The Journal of Strength \& Conditioning Research, vol.28, no.10, pp. 3001-3011, 2014.

[36] Laursen, P., \& Buchheit, M, Science and Application of High-Intensity Interval Training., USA: Human Kinetics, 2019.

[37] Gillen, J. B., \& Gibala, M. J., "Is high-intensity interval training a time-efficient exercise strategy to improve health and fitness?". Applied physiology, nutrition, and metabolism,," vol. 39, no. 3, pp. 409-412, 2014.

[38] Laursen, P. B., "Training for intense exercise performance: high - intensity or high - volume training," Scandinavian journal of medicine \& science in sports, vol. 20, pp. 1-10, 2010.

[39] Kinnunen, J. V., Piitulainen, H., \& Piirainen, J. M., "Neuromuscular adaptations to short-term high-intensity interval training in female ice-hockey players.," The Journal of Strength \& Conditioning Research, vol. 33, no. 2, pp. 479-485, 2019.

[40] Heydari, M., Boutcher, Y. N., \& Boutcher, S. H, "High-intensity intermittent exercise and cardiovascular and autonomic function," Clinical autonomic research, vol. 23, no. 1, pp. 57-65, 2013.

[41] Noroozi, F., Eisapareh, K., Bahadori, A., Ghahremani, L., Cousins, R., \& Mokarami, H., "Development and validation of dust exposure prevention questionnaire for cardiovascular patients based on the health belief model," BMC Public Health, vol. 20, no. 1, pp. 1-11, 2020.

[42] Tomoliyus, M., Tirtawirya, D., Sudarko, R. A., Arif, H. A., \& Widodo, H., "The Contest Validation of Circuit 
Trainning Design to Improve Biomotor Components in Table Tennis Performance." In 2nd yogyakarta International Seminar on Health, physical education, and sport science (YISHPESS 2018) and 1st conference on interdisciplinary approach in sport alantis press, (cois 2018) pp. 336-33-8, 2018.

[43] D. Yudhistira. \&. Tomoliyus, "Content Validity of Agility Test in Karate Kumite Category," Journal of Human Movement and Sports Sciences, vol. 8, no. 5, pp. 211-216, 2020.

[44] Wilpers, A., Bahtiyar, M. O., Wall, D., Kobler, K., Sadler, L. S., Dixon, J. K., \& Kennedy, H. P., "Modified Delphi Study on Nursing Practice and Science in Fetal Care," Journal of Obstetric, Gynecologic \& Neonatal Nursing, vol. 50, no. 1, pp. 55-67., 2021.

[45] C. H. Lawshe, "A quantitative approach to content validity," Personnel psychology, vol. 28, no. 4, pp. 563-575, 1975.

[46] Sucipto, S., Tarigan, B., Ma'mun, A., \& Yudiana, Y., "Content Validity of the Enjoyment Instrument in Physical Education Learning: A Field Study." The 3rd International Conference on Sport Science, Health, and Physical Education (ICSSHPE 20, 2019.)

[47] Chaabene, H., Negra, Y., Capranica, L., Prieske, O., \& Granacher, "A Needs analysis of karate kumite with Recommendations for Performance Testing and Training," Strength \& Conditioning Journal, vol. 41, no. 3, pp. 35-46, 2019.

[48] Iide, K., Imamura, H., Yoshimura, Y., Yamashita, A., Miyahara, K., Miyamoto, N., \& Moriwaki, C., "Physiological responses of simulated karate sparring matches in young men and boys," The Journal of Strength \& Conditioning Research, vol. 22, no. 3, pp. 839-844, 2008.

[49] T. O. Bompa, "Primer on periodization," USA Roller Sport, vol. 24, no. 1/2, pp. 70-74, 2012.

[50] İ. Marangoz, "A Different Approach to the Determination of Aerobic Capacity: Relative Endurance Method.," International Journal of Applied Exercise Physiology, , vol. 9, no. 8, pp. 42-46, 2020.

[51] Alver, B. A., Sell, K., \& Deuster, P. A. "NSCA's essentials of tactical strength and conditioning", USA: Human Kinetics, 2017.

[52] Van der Kruk, E., van der Helm, F. C. T., Veeger, H. E. J., $\&$ Schwab, A. L. "Power in sports: a literature review on the application, assumptions, and terminology of mechanical power in sport research," Journal of biomechanics, vol. 79, no. 1, pp. 1-14, 2018.

[53] Orssatto, L. B., Bezerra, E. S., Shield, A. J., \& Trajano, G. S "Is power training effective to produce muscle hypertrophy in older adults? A systematic review and meta-analysis," Applied Physiology, Nutrition, and Metabolism, vol. 45, no. 9, pp. 1031-1040, 2020.

[54] Harsono, Latihan Kondisi Fisik. Bandung: PT Remaja Rosdakarya, 2018.

[55] S. Bartram, High-Intensity Interval Training for Women: Burn More Fat in Less Time with HIIT Workouts You Can Do Anywhere, USA: dorling kindersly, 2015

[56] Monks, L., Seo, M. W., Kim, H. B., Jung, H. C., \& Song, J. $\mathrm{K}$, "High-intensity interval training and athletic performance in taekwondo athletes," The Journal of sports medicine and physical fitness, vol. 57, no. 10, pp. 12552-1260, 2017.

[57] Kraemer, W. J., \& Fleck, S. J., Optimizing strength training: designing nonlinear periodization workouts, USA: Human Kinetics., 2007.

[58] Simão, R., Spineti, J., de Salles, B. F., Matta, T., Fernandes, L., Fleck, S. J., ... \& Strom-Olsen, H. E., "Comparison between nonlinear and linear periodized resistance training: hypertrophic and strength effects.," The Journal of strength \& conditioning, vol.23, no.5, pp.1389-1395, 2012.

[59] S. E. Embretson, "Construct validity: A universal validity system or just another test evaluation procedure?," Educational Researcher, vol. 36, no. 8, pp. 449-455., 2007.

[60] , Hsu, I. Y., Su, T. S., Kao, C. S., Shu, Y. L., Lin, P. R., \& Tseng, J. M. "Analysis of business safety performance by structural equation model," Safety Science, vol. 50, no. 1, pp. 1-11, 2012.

[61] Hendriyadi, "Validity Content: Preliminary Development of Questionnaire,," journal of Management Research and Business. FE-UNIAT, vol. 2, no. 2, p. 169-178, 2017.

[62] S. Nugroho, A. Nasrulloh, T. H. Karyono, R. Dwihandaka, and K. W. Pratama, "Effect of intensity and interval levels of trapping circuit training on the physical condition of badminton players," J. Phys. Educ. Sport, vol. 21, no. July, pp. 1981-1987, 2021, doi: 10.7752/jpes.2021.s3252.

[63] A. Nasrulloh et al., "Tricet Method to Increase the Hypertrophy Muscle,” J. Phys. Conf. Ser., vol. 1529, no. 3, 2020, doi: 10.1088/1742-6596/1529/3/032006. 